\section{EMBRYRIDDLE}

Aeronautical University

SCHOLARLY COMMONS
Journal of Aviation/Aerospace

Education \& Research

Volume 27

Number 12017 NTAS Conference Selected

Articles

Article 2

2018

\title{
Adaptive Learning Pedagogy of Universal Design for Learning (UDL) for Multimodal Training
}

\author{
Ziho Kang \\ University of Oklahoma, zihokang@ou.edu \\ Mattlyn R. Dragoo \\ Lauren Yeagle \\ Randa L. Shehab \\ Han Yuan
}

See next page for additional authors

Follow this and additional works at: https://commons.erau.edu/jaaer

Part of the Aviation and Space Education Commons, Educational Assessment, Evaluation, and Research Commons, and the Management and Operations Commons

\section{Scholarly Commons Citation}

Kang, Z., , , , , , \& (2018). Adaptive Learning Pedagogy of Universal Design for Learning (UDL) for Multimodal Training. Journal of Aviation/Aerospace Education \& Research, 27(1). https://doi.org/ 10.15394/jaaer.2018.1752

This Article is brought to you for free and open access by the Journals at Scholarly Commons. It has been accepted for inclusion in Journal of Aviation/Aerospace Education \& Research by an authorized administrator of Scholarly Commons. For more information, please contact commons@erau.edu. 
Adaptive Learning Pedagogy of Universal Design for Learning (UDL) for Multimodal Training

Author(s)

Ziho Kang, Mattlyn R. Dragoo, Lauren Yeagle, Randa L. Shehab, Han Yuan, Lei Ding, and Stephen G. West 


\section{Introduction}

\section{FAA Training Through Universal Design for Learning (UDL)}

The Federal Aviation Administration (FAA) has been searching for effective ways to train a large number of air traffic control specialists (ATCSs) to fill the growing number of vacant positions; however, it has been challenging to increase the trainees' passing rate. It might be possible that the traditional ways of teaching that often use a single information display type (e.g. text summarized in PowerPoint slides, providing information in a fixed format that prevents customization based on each trainee's needs, or being unable to provide multiple means to engage in activities or manage anxiety) can affect the performance of the trainees if diversified needs among the students exist. For example, some trainees who are identified as "average" might show similar performances regardless of whether the information is presented visually or verbally. Conversely, other trainees might perform exceptionally well when visual information is

presented, yet perform poorly when auditory information is played. If a course was taught using mostly verbal instructions, then those other trainees would not perform well unless they are provided with appropriate scaffolding techniques that might give them time to adapt.

To address the students' needs, the concept of Universal Design for Learning (UDL) was introduced to provide as many diversified teaching methods as possible based on three classifications (i.e. information display methods, action and expression methods, and engagement methods) (Hall, Meyer, \& Rose, 2012; Hitchcock, Meyer, Rose, \& Jackson, 2002; Rose, 2000; Rose \& Meyer, 2002). The UDL approaches have been applied not only in K-12 classrooms (Edyburn, 2010; Hall et al., 2012; Rose, Meyer, \& Hitchcock, 2005) but also in postsecondary education (Dean, Lee-Post, \& Hapke, 2017; Morra \& Reynolds, 2010; Rose, Harbour, Johnston, Daley, \& Abarbanell, 2006; Schelly, Davies, \& Spooner, 2011). However, 
creating such diversified materials takes significant time and effort, requiring a better approach to reduce efforts while still obtaining similar increases of performances.

One of the approaches that might diminish the efforts of developing UDL-based materials is the identification of preferred learning styles of the trainee population. While many models of learning styles exist (Hawk \& Shah, 2007), the Index of Learning Styles (ILS) is unique in its approach. The ILS divides student characteristics largely based on four classifications: perception, input, processing, and understanding (Felder \& Brent, 2005; Felder \& Silverman, 1988; Felder \& Soloman, 2000), and the learning styles of the student can be assessed through asking approximately forty binary choice questions (Felder \& Soloman, n.d.). This is a highly respected model that has been applied to a diverse range of areas, some of which include adaptive e-learning systems (Hwang, Sung, Hung, \& Huang, 2013), graduate nursing programs (Gonzales et al., 2017), and even web-based educational gaming (Khenissi et al., 2016).

Although UDL and ILS are very closely related, there is no clear mapping process among the three classifications of UDL and the four classifications of ILS. A better mapping of the classifications would effectively identify and address possible issues with the traditional teaching approaches, saving cost, time, and effort to develop the materials and leading to increased student performance.

\section{Learning Styles}

Felder and Silverman (1988) published one of the most widely cited pieces of work on the topic of learning styles. In it, they outlined four learning style dimensions and developed a web-based questionnaire called the Index of Learning Styles (ILS) designed to determine one's learning style preferences. The proposed model can be seen in Table 1. Originally, the publication also included a fifth dimension - inductive/deductive - but it was later removed as 
the authors believed that induction is ultimately the "best" method of learning. Then, the appropriate teaching methods were outlined according to each learning style. It is noted that a person can have both traits (e.g. being both active and reflective) with a preference of each trait being mild, moderate, or strong.

Table 1

Felder-Silverman Model for Learning Styles (Felder and Silverman, 1988)

\begin{tabular}{cc|cc}
\hline \multicolumn{2}{c|}{ Preferred learning style } & \multicolumn{2}{c}{ Corresponding teaching style } \\
\hline Categorization & Levels & Categorization & Levels \\
\hline \multirow{2}{*}{ Processing } & Active & Student participation & Active \\
& Reflective & Passive \\
\hline \multirow{2}{*}{ Perception } & Sensory & Content & Concrete \\
& Intuitive & Presentation & Abstract \\
\hline \multirow{2}{*}{ Input } & Visual & & Verbal \\
& Auditory & \multirow{2}{*}{ Perspective } & $\begin{array}{c}\text { Sequential } \\
\text { Global }\end{array}$ \\
\hline \multirow{2}{*}{ Understanding } & Sequential & & \\
& Global
\end{tabular}

Refined summary of the learning styles explained by Felder and Silverman (1988) and Felder and Soloman (2000) is as follows.

Active vs. reflective refers to the method by which information is processed. Active learners prefer active experimentation or discussions to better learn, whereas reflective learners need time to introspectively examine the information. Active learners like to try something first to see what would happen, whereas reflective learners like to thoroughly think about the processes and consequences first before indulging in experiments. Reflective learners prefer working alone or with those they know well. Active learners might have difficulties attending lectures that do not have interactions or physical activities. 
Sensing vs. intuitive refers to the way in which students perceive the information that is presented to them. Sensing involves observation and gathering data through the physical senses, whereas intuitive learners prefer an indirect method of perception through insights, hunches, and speculation. Put simply, sensing learners (or sensors) like data and facts, while intuitive learners (or intuitors) like theories and concepts. Sensors are patient with details, good at memorizing facts, and prefer hands-on laboratory sessions. Sensors prefer practical applications and are careful on what they do, whereas intuitors are more innovative and accomplish tasks more quickly. Intuitors can be better at grasping new concepts and are more comfortable with abstractions and mathematical formulations, but they dislike repetition. College engineering courses are designed to favor intuitors because they emphasize concepts rather than facts; however, most engineering students are sensors.

Visual vs. verbal refers to a student's preferred input modality. Visual learners excel at remembering pictures, images, and demonstrations, whereas verbal learners learn best from written or spoken explanations. Most college-aged students tend to be visual learners while most college courses are taught verbally, and teaching materials are written on boards or provided as text-heavy handouts.

$\underline{\text { Sequential vs. global refers to the way in which students progress toward understanding }}$ content. While most college courses are taught very sequentially by following a strict calendar that dictates when to move onto the next subject, some students prefer to learn the major underlying concepts and context before delving into specifics. Sequential learners prefer following logical steps, whereas global learners tend to first try to grasp the whole picture by randomly processing bits of information; then as they learn, they come to a stage when they understand everything at once. 
The ILS model utilizes a scaled system to classify each student's learning styles. Each student has preferences in each of these categories and the ILS questionnaire provides a simple yet effective means of determining the learning styles that any particular student tends to favor. There are 44 redundant yet differently expressed questions to assess each learning style classification.

The ILS provides an excellent means to define and measure each student's learning style, but the suggested teaching approaches are not very specific and are not directly associated with the UDL classifications. The next section describes some details of the UDL classifications.

\section{Universal Design for Learning}

Universal Design for Learning was originally developed to meet the needs of students with disabilities in the classroom and is still used for such purposes (Fuentes, Castro, Casas, Vallejo, \& Zuñiga, 2016); however, its principles can be expanded to the general classroom to include students of all learning types. This is accomplished by providing flexible means of representation, action and expression, and engagement to students (Rose \& Meyer, 2002). Universal Design for Learning considers the different neural networks (recognition, strategic, and affective) that are engaged during learning. Recognition networks dictate the "what" of learning, regarding the content that is displayed to students. These networks assist in finding patterns and making sense of information. Strategic networks are responsible for the "how" of learning; or, they determine the strategy and plan for completing an assigned task. Last,

affective networks engage the purpose, or the "why" of learning (Hall et al., 2012). Combined, these networks illustrate how a student perceives information, their strategy to understand that information, and their motivation for pursing an understanding. 
The first guideline of UDL, representation, seeks to provide multiple pathways to display information to students. To accomplish this, instructors can provide many examples and counter-examples of strategies and methods for solving a problem. They can highlight critical characteristics to support bottom-up processes and to ease in understanding new information. To scaffold top-bottom processing, instructors can give background information and connect concepts from previous lessons. Multiple forms of media can support the learning styles of many students and provide redundancy to the lesson (Rose \& Meyer, 2002). In detail, the first guideline is associated with offering options for (1) relaying perceptual information (e.g. visual and auditory), (2) representing vocabulary, mathematical notations, and symbols, and (3) providing options for comprehension (UDL Guidelines, 2014). Overall, these methods should be flexible and adaptable to the classroom to meet the needs of the students.

The second guideline seeks to provide multiple methods for action and expression, detailing the problem-solving skills a student uses. To develop this proficiency, instructors can show many correct examples of solving a problem so that students can form patterns for answering the problem on their own. In addition, students need many opportunities to practice with feedback to develop the problem-solving approach and apply new skills (Rose \& Meyer, 2002). In detail, the second guideline is associated with providing options for (1) executing physical actions and communication and (2) developing executive functions to reach long-term goals (UDL Guidelines, 2014).

The third guideline provides multiple opportunities for engagement in the classroom. This includes creating a suitable and adaptable difficulty level to best motivate students. If a task is too easy, students are likely to become bored and disengage. Conversely, if the challenge is too difficult, students can become frustrated and give up on learning the material. It is important 
for students to be able to self-regulate their own progress and set goals for themselves (Rose \& Meyer, 2002). In a broader manner, the third guideline is associated with providing methods to (1) promote interest and (2) provide options for sustaining effort and self-regulations (UDL Guidelines, 2014).

Most applications of UDL are realized in the K-12 classroom; however, more research and implementation strategies are being applied to higher education. Means of representation should teach students how to use information beneficially, exceeding expectations of simply having access to information. This includes teaching students how to discover, consolidate, and apply information into the context of learning. Supporting students in expression includes providing review periods, feedback sessions for assignments, and additional readings to supplement class materials. Engagement in higher education allows students to motivate themselves to meet personal learning criteria. Professors can encourage passion for the field of study and give students options with opportunities for self-regulation (Rose et al., 2006). These principles are applicable to online courses in higher education and mobile learning, as well (Dell, Dell, \& Blackwell, 2015; Tobin, 2016).

An issue with implementing the UDL methods is that they require substantial cost, time, and effort to provide all the diversified ways of learning. In addition, the FAA has a policy to provide the same materials and instructional guides to the students, meaning an instructor is not allowed to apply different teaching methods based on the individual student's needs.

Furthermore, the UDL approach takes more time to teach compared to the traditional approach due to the multiple sources of teaching materials and interactions required. The intensive training and limited time of students and instructors require adapted implementation of UDL methods to accommodate these constraints. 


\section{Proposed Approaches}

The proposed mapping of the learning styles with the UDL methods is provided in Tables 2, 3, and 4. Specific implementation examples based on the mapping are shown in Tables 2 and 3. Mappings for information representation and comprehension of UDL are provided in Table 2, and Table 3 provides the mappings for action and expression of UDL. Since all learning styles would benefit from engagement options, Table 4 only provides examples of the engagement of UDL.

It is important to note that we can easily develop ways to address the combinations of the learning styles using the proposed mapping approach. As an example, we could provide visual prompts of each step within a sequential process for students who are "visual" and "sequential"

learners. Another example includes forming a study group for students, brainstorming examples, and performing a what-if analysis of those brainstormed examples for "active," "sensing," and "global" learners. The proposed tables enable us to effectively combine implementation examples based on the four learning style classifications. 
Table 2

Proposed Mapping of Learning Styles and UDL Method 1 (Information Representation and Comprehension)

\begin{tabular}{|c|c|c|}
\hline UDL & $\begin{array}{l}\text { Learning } \\
\text { styles }\end{array}$ & $\begin{array}{l}\text { Mapping of UDL and learning styles through practical scaffolding } \\
\text { implementations }\end{array}$ \\
\hline $\begin{array}{l}\text { 1.1. Provide options } \\
\text { of customize the } \\
\text { display of } \\
\text { information }\end{array}$ & $\begin{array}{l}\text { (ALL) } \\
\text { All types }\end{array}$ & $\begin{array}{l}\text { ALL.1.1.1. Provide options to change the size or contrast of text, figures, graphs, or tables. } \\
\text { ALL.1.1.2. Provide options to highlight information for emphasis. } \\
\text { ALL.1.1.3. Provide video or audio recordings that allows options (e.g. change speed or } \\
\text { volume, toggle caption). }\end{array}$ \\
\hline $\begin{array}{l}\text { 1.2. Offer } \\
\text { alternatives to } \\
\text { visual information } \\
\text { (e.g. figures, graphs) }\end{array}$ & $\begin{array}{l}\text { (VER) } \\
\text { Verbal } \\
\text { learners }\end{array}$ & $\begin{array}{l}\text { VER.1.2.1. Provide auditory and text descriptions. } \\
\text { VER.1.2.2. Provide auditory queues for key concepts. } \\
\text { VER.1.2.3. Provide text-to-speech software. } \\
\text { VER.1.2.4. Provide audio clips as needed. }\end{array}$ \\
\hline $\begin{array}{l}\text { 1.3. Offer } \\
\text { alternatives to } \\
\text { auditory } \\
\text { information }\end{array}$ & $\begin{array}{l}\text { (VIS) } \\
\text { Visual } \\
\text { learners }\end{array}$ & $\begin{array}{l}\text { VIS.1.3.1. Provide additional visual guidance as a scaffold if only verbal guidance is } \\
\text { provided. } \\
\text { VIS.1.3.2. Provide captions. } \\
\text { VIS.1.3.3. Provide speech-to-text software. } \\
\text { VIS.1.3.4. Provide video clips as needed. }\end{array}$ \\
\hline $\begin{array}{l}\text { 1.4. Provide } \\
\text { scaffolding options } \\
\text { for comprehending } \\
\text { vocabulary or } \\
\text { symbols }\end{array}$ & $\begin{array}{l}\text { (ALL) } \\
\text { All types }\end{array}$ & $\begin{array}{l}\text { ALL.1.4.1. Connect vocabulary or symbols that promote connection to previous } \\
\text { experience or knowledge. } \\
\text { ALL.1.4.2. Highlight how complex vocabulary can be composed of simpler words. } \\
\text { ALL.1.4.3. Embed hyperlinks, footnotes, or illustrations to further explain vocabulary or } \\
\text { symbols. }\end{array}$ \\
\hline \multirow[t]{8}{*}{$\begin{array}{l}\text { 1.5. Provide } \\
\text { scaffolding options } \\
\text { for comprehending } \\
\text { key concepts }\end{array}$} & $\begin{array}{l}\text { (ALL) } \\
\text { All types }\end{array}$ & $\begin{array}{l}\text { ALL.1.5.1. Show explicit links among the slides, text, and lab sessions (e.g. if a slide is from } \\
\text { a text book, then show the narrowed range of the page numbers) } \\
\text { ALL.1.5.2. Use analogy and metaphors as needed. }\end{array}$ \\
\hline & $\begin{array}{l}\text { (ACT) } \\
\text { Active } \\
\text { learners }\end{array}$ & $\begin{array}{l}\text { ACT.1.5.3. Provide lectures that include problem-solving activities (approx. } 5 \text { minutes or } \\
\text { less per activity). } \\
\text { ACT.1.5.4. Provide material links of real life examples. }\end{array}$ \\
\hline & $\begin{array}{l}\text { (REF) } \\
\text { Reflective } \\
\text { learners }\end{array}$ & $\begin{array}{l}\text { REF.1.5.5. Provide occasional pause during lectures and lab sessions. } \\
\text { REF.1.5.6. Provide material links that emphasize fundamental understanding, }\end{array}$ \\
\hline & $\begin{array}{l}\text { (SEN) } \\
\text { Sensing } \\
\text { learners }\end{array}$ & $\begin{array}{l}\text { SEN.1.5.7. Provide links to facts, data, and observable phenomena. } \\
\text { SEN.1.5.8. Provide material links that emphasize specific examples. }\end{array}$ \\
\hline & $\begin{array}{l}\text { (INT) } \\
\text { Intuitive } \\
\text { learners }\end{array}$ & $\begin{array}{l}\text { INT.1.5.9. Show the relationships and associated interpretations among the concepts, } \\
\text { procedures, and theories. }\end{array}$ \\
\hline & $\begin{array}{l}\text { (SEQ) } \\
\text { Sequential } \\
\text { learners }\end{array}$ & $\begin{array}{l}\text { SEQ.1.5.10. Give explicit prompts (or cues) for each step in a sequential process. } \\
\text { SEQ.1.5.11. Provide options to change the organization and layout of the class contents. } \\
\text { SEQ.1.5.12. Progressively release information (a.k.a sequential highlighting). }\end{array}$ \\
\hline & $\begin{array}{l}\text { (GLO) } \\
\text { Global } \\
\text { learners }\end{array}$ & $\begin{array}{l}\text { GLO.1.5.13. Provide options to connect the new class contents with the contents that the } \\
\text { students already know. } \\
\text { GLO.1.5.14. Provide opportunities to synthesize concepts (e.g. expose them with } \\
\text { advanced concepts before the concepts would normally be introduced). }\end{array}$ \\
\hline & & GLO.1.5.15. Provide "What-if" questions. \\
\hline
\end{tabular}


Table 3

Proposed Mapping of Learning Styles and UDL Method 2 (Action and Expression)

\begin{tabular}{|c|c|c|}
\hline $\begin{array}{l}\text { UDL method } \\
\text { details }\end{array}$ & $\begin{array}{l}\text { Learning } \\
\text { styles }\end{array}$ & $\begin{array}{l}\text { Mapping of UDL and learning styles through practical scaffolding } \\
\text { implementations }\end{array}$ \\
\hline $\begin{array}{l}\text { 2.1. Provide } \\
\text { multiple media for } \\
\text { communication }\end{array}$ & $\begin{array}{l}\text { (ALL) } \\
\text { All types }\end{array}$ & $\begin{array}{l}\text { ALL.2.1.1. Provide interactive online tools embedded within the teaching materials for } \\
\text { effective communication between the instructors and students. } \\
\text { ALL.2.1.2. Provide exercises that allow alternative problem solution procedures or } \\
\text { actions. } \\
\text { ALL.2.1.3. Show progress representations and prompt learners to identify the feedback } \\
\text { or advice that they are seeking. } \\
\text { ALL.2.1.4. Provide interactive checklists/rubrics and links to multiple examples of how } \\
\text { students acted and expressed correct answers. }\end{array}$ \\
\hline \multirow[t]{8}{*}{$\begin{array}{l}\text { 2.2. Provide } \\
\text { alternative ways to } \\
\text { express themselves }\end{array}$} & $\begin{array}{l}\text { (ACT) } \\
\text { Active } \\
\text { learners }\end{array}$ & $\begin{array}{l}\text { ACT.2.2.1. Provide options to create a study group: Members can take turns explaining } \\
\text { different concepts to foster discussion or take turns asking/answering questions. } \\
\text { ACT.2.2.2. Provide hands on experience examples. }\end{array}$ \\
\hline & $\begin{array}{l}\text { (REF) } \\
\text { Reflective } \\
\text { learners }\end{array}$ & $\begin{array}{l}\text { REF.2.2.3. Allow some time to the students to write their own short summaries of the } \\
\text { slides, textbooks, and lab session materials. }\end{array}$ \\
\hline & $\begin{array}{l}\text { (SEN) } \\
\text { Sensing } \\
\text { learners }\end{array}$ & $\begin{array}{l}\text { SEN.2.2.4. Allow the students to request more examples: Provide free access to the } \\
\text { additional examples not explained to them during time limited lectures or lab sessions. }\end{array}$ \\
\hline & $\begin{array}{l}\text { (INT) } \\
\text { Intuitive } \\
\text { learners }\end{array}$ & $\begin{array}{l}\text { INT.2.2.5. Allow the students to request additional interpretations of, and relationships } \\
\text { among, the concepts, procedures, and theories. }\end{array}$ \\
\hline & $\begin{array}{l}\text { (VIS) Visual } \\
\text { learners }\end{array}$ & $\begin{array}{l}\text { VIS.2.2.6. Provide an opportunity to foster visual imagery (as an intermediate step) } \\
\text { before they provide answers or execute actions. }\end{array}$ \\
\hline & $\begin{array}{l}\text { (VER) } \\
\text { Verbal } \\
\text { learners }\end{array}$ & $\begin{array}{l}\text { VER.2.2.7. Provide an opportunity to apply the think-aloud method or to paraphrase the } \\
\text { procedures (as an intermediate step) before they answer or execute actions. }\end{array}$ \\
\hline & $\begin{array}{l}\text { (SEQ) } \\
\text { Sequential } \\
\text { learners }\end{array}$ & $\begin{array}{l}\text { SEQ.2.2.8. Provide feedback through having them express their logical steps or critical } \\
\text { thinking processes. }\end{array}$ \\
\hline & $\begin{array}{l}\text { (GLO) } \\
\text { Global } \\
\text { learners }\end{array}$ & $\begin{array}{l}\text { GLO.2.2.9. Let the students first devise their own methods for solving problems rather } \\
\text { than forcing the instructor's strategy. }\end{array}$ \\
\hline
\end{tabular}

The proposed adapted implementation procedure is provided in Figure 1. The procedure is designed to effectively use the time and resources available to implement UDL methods into the current curriculum. In detail, after assessing the overall learning styles of the student population using Felder and Silverman's (1988) ILS, we would identify some of the prominent learning style combinations among all identified combinations. For example, if $70 \%$ of the population is active+sensing+visual+global, $30 \%$ showing other combinations, then we would first address the needs of the $70 \%$ of the population. After, the UDL implementation examples 
are extracted from the mapped tables, taking the highest immediate priorities for implementation to create the most impact given the limited time and resources. The UDL examples for less prominent learning style combination would be implemented at a later stage when additional time and resources are available.

Table 4

UDL Method 3 (Engagement) Classifications Regardless of Learning Styles

\begin{tabular}{|c|c|}
\hline $\begin{array}{l}\text { 3.1. Provide options } \\
\text { for recruiting }\end{array}$ & $\begin{array}{l}\text { 3.1.1. Provide what challenges are to be expected and what are the types of awards or recognitions } \\
\text { available per area and/or topic. }\end{array}$ \\
\hline interest & $\begin{array}{l}\text { 3.1.2. Provide checklists, sticky notes, and electronic reminders for them to follow up during the } \\
\text { training process. }\end{array}$ \\
\hline & 3.1.3. Allow the students to create their own expectations and necessary activities. \\
\hline & $\begin{array}{l}\text { 3.1.4. Provide tasks that require active participation, exploration, and experimentation. Passive learning } \\
\text { does not help any learning styles. }\end{array}$ \\
\hline & 3.1.5. Encourage division of long-term goals into short-term objectives. \\
\hline & 3.1.6. Demonstrate the use of available technology and information access/customization methods. \\
\hline & 3.1.7. Vary the levels of novelty or risk. \\
\hline & 3.1.8. Vary the levels of sensory stimulation. \\
\hline & 3.1.9. Vary the degrees of freedom for acceptable performance. \\
\hline & 3.1.10. Address language barriers and cultural differences. \\
\hline $\begin{array}{l}\text { 3.2. Provide options } \\
\text { for sustaining effort }\end{array}$ & $\begin{array}{l}\text { 3.2.1. Provide frequent, timely, and specific feedback with emphasis on identification of patterns of } \\
\text { errors, efforts, and improvements rather than relative performance. }\end{array}$ \\
\hline and persistence. & $\begin{array}{l}\text { 3.2.2. Provide self-regulatory prompts, guidelines, rubrics, checklists to reduce stress and aggressive } \\
\text { actions in response to frustration. }\end{array}$ \\
\hline & 3.2.3. Provide feedback on strengths and weaknesses. \\
\hline $\begin{array}{l}\text { 3.3. Provide options } \\
\text { for self-regulation }\end{array}$ & $\begin{array}{l}\text { 3.3.1. Provide scaffolds or feedback to the students so that they can seek emotional support, cope with } \\
\text { schedules, and apply natural aptitudes (e.g. having them think "how can I improve on this topic?" } \\
\text { rather than "I'm not good at this topic") }\end{array}$ \\
\hline & $\begin{array}{l}\text { 3.3.2. Provide scaffolds so that the students can monitor their own progress (e.g. charts, feedback } \\
\text { notes). }\end{array}$ \\
\hline & 3.3.3. Create school-wide programs to support positive behaviors. \\
\hline
\end{tabular}

This approach will enable us to better identify the more critical mismatches between the learning styles and the current teaching methods based on the prominent learning style combinations of the student population. For example, if it turns out that the majority of the students are visual learners, yet most of the laboratory sessions are provided verbally (e.g. verbal intensive communications during En Route or Terminal Radar simulation sessions), then we can 
apply the mapped UDL examples into the laboratory settings by providing a visual aid as a scaffold until the students fully adapt to the environment. It is noted that we want to emphasize less on the individual burdens that might increase for each instructor and more on implementing the UDL methods into the teaching materials (e.g. developing software that supports UDL) so that the students are empowered to choose different learning options based on their needs. In other words, a "universal" implementation is required so that all students have the opportunity to equally access the UDL-based materials and interaction approaches, which will meet the requirements of the FAA's training policies.

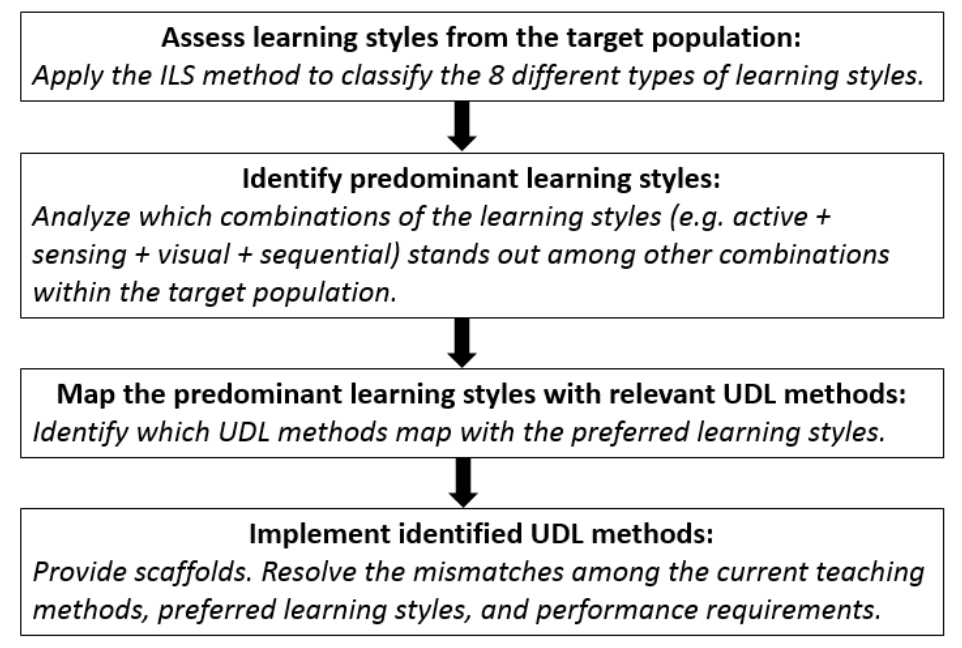

Note: Apply other less predominant learning styles if time and resources are available.

Figure 1. Proposed adapted implementation approach.

\section{Pilot Study}

In order to benchmark the effectiveness of mapping student learning styles to the classroom environment, an experiment was performed with a small group of four qualified students at the University of Oklahoma (OU) Aviation Laboratory with the goal of identifying methods to better and more efficiently train ATC candidates. The purpose of the pilot study was to verify whether our proposed approaches would indeed be effective in identifying the learning 
styles and needs of the students. In addition, it is important to note that the proposed approaches would show different mapping results with different sets of student population.

Learning style assessments and classroom observations were conducted to determine which UDL methods should be implemented with highest priorities and how the UDL methods are implemented in the current curriculum.

Four students, with mean age of $21.2(S D=1.3)$ who have been preparing to enter the FAA Academy training program, participated in the learning style assessment. The students were taking courses such as AVIA 4013 En Route Radar Lab, AVIA 4023 Tracon Radar Lab, and the AVIA 1013 Intro to Air Traffic Control classes at the OU Aviation Laboratory. In addition, classroom observations were conducted by two analysts to see whether, and how, any of the UDL methods were already being applied.

For the learning style assessment, the students were given the ILS questionnaire to determine their preferred learning style. We strictly followed Felder and Silverman's (1988) ILS approach. The ILS approach provides 44 questions (11 per classification). For each classification, subtract the tallied number of answers that relate to one learning style (e.g. verbal) from the higher tallied number of answers that relates to the other learning style (e.g. visual). If the subtracted amount is positive, then the person is classified as a visual learner; otherwise, the person is a verbal learner. For example, out of 11 questions for the "input" classification, if a student provides nine answers that relate to visual and two answers that relate to verbal, then the 9-2 returns a positive seven; therefore, the student is classified as a visual learner. Sample ILS questions are provided in Table 5 based on each classification.

To better analyze the ILS evaluation results, we first applied the aggregation procedure provided by Feldman and Silverman (1988). In addition, we performed statistical tests to 
identify whether there would be significant differences between the learning styles within each of the classification by using the tallies of the students' answers per learning style. Finally, we identified the prominent learning style combinations and identified the mapped UDL methods for those learning styles.

For the classroom observation, the two analysts (i.e. authors) attended several classes and observed how the lectures and laboratory sessions were taught. The analysts observed from the back of the classrooms and simulation rooms in order to minimize any possible distraction. These observations were instrumental in identifying the current teaching methods being applied in the classroom.

Table 5

Sample ILS Questions and Classifications

\begin{tabular}{|c|c|c|}
\hline Sample question & & Classification \\
\hline $\begin{array}{l}\text { I understand something } \\
\text { better after I }\end{array}$ & $\begin{array}{l}\text { a) try it out } \\
\text { b) think it through }\end{array}$ & $\begin{array}{l}\text { Active } \\
\text { Reflective }\end{array}$ \\
\hline I prefer to study & $\begin{array}{l}\text { a) in a group } \\
\text { b) alone }\end{array}$ & $\begin{array}{l}\text { Active } \\
\text { Reflective }\end{array}$ \\
\hline $\begin{array}{l}\text { If I were a teacher, I would } \\
\text { rather teach a course }\end{array}$ & $\begin{array}{l}\text { a) that deals with facts and real life situations } \\
\text { b) that deals with ideas or theories }\end{array}$ & $\begin{array}{l}\text { Sensing } \\
\text { Intuitive }\end{array}$ \\
\hline $\begin{array}{l}\text { In reading nonfiction, I } \\
\text { prefer }\end{array}$ & $\begin{array}{l}\text { a) something that teaches me new facts or tells me how to do something } \\
\text { b) something that gives me new ideas to think about }\end{array}$ & $\begin{array}{l}\text { Sensing } \\
\text { Intuitive }\end{array}$ \\
\hline $\begin{array}{l}\text { When I think about what I } \\
\text { did yesterday, I am most } \\
\text { likely to get }\end{array}$ & $\begin{array}{l}\text { a) a picture } \\
\text { b) words }\end{array}$ & $\begin{array}{l}\text { Visual } \\
\text { Verbal }\end{array}$ \\
\hline $\begin{array}{l}\text { When I get directions to a } \\
\text { new place, I prefer }\end{array}$ & $\begin{array}{l}\text { a) a map } \\
\text { b) written or verbal directions }\end{array}$ & $\begin{array}{l}\text { Visual } \\
\text { Verbal }\end{array}$ \\
\hline $\begin{array}{l}\text { It is more important to me } \\
\text { that an instructor }\end{array}$ & $\begin{array}{l}\text { a) lay out material in clear sequential steps } \\
\text { b) give me an overall picture and relate materials to other subjects }\end{array}$ & $\begin{array}{l}\text { Sequential } \\
\text { Global }\end{array}$ \\
\hline When I solve problems & $\begin{array}{l}\text { a) I usually work my way to the solutions one step at a time } \\
\text { b) I often just see the solutions but then have to struggle to figure out the } \\
\text { steps to get to them }\end{array}$ & $\begin{array}{l}\text { Sequential } \\
\text { Global }\end{array}$ \\
\hline
\end{tabular}

Note. Following Felder and Silverman's (1988) ILS evaluation guidelines, a total of 44 questions were asked. 


\section{Pilot Study Results}

The purpose of the pilot study was to verify whether the proposed approaches could identify possible ways to address the small group's needs based on current practices at the Department of Aviation at OU. These proposed approaches could show different mapping results with different sets of student population. It is important to note that the purpose of this results section is to show the analysis procedure of the proposed approaches rather than showing a generalized outcome of a student population.

The results of the ILS approach are provided in Figure 2. We can see that the majority of the participants preferred active, sensing, visual, and global. To better understand the similarity of the students' learning styles, the detailed assessment results are created into a tree shown in Figure 3.

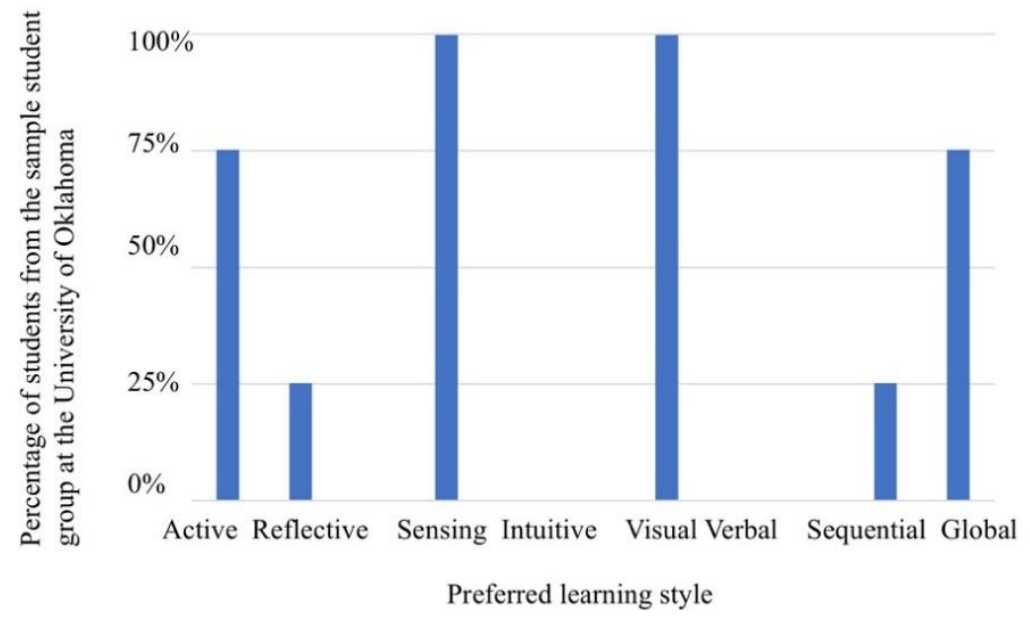

Figure 2. Percentage of OU Aviation students with assessed learning style using the ILS approach $(\mathrm{N}=4)$.

Based on the results we can determine that there are two distinctive preferred learning styles: (1) type VSSR: Visual+Sensing+Sequential+Reflective and (2) type VSGA: Visual+Sensing+Global+Active. Using Tables 1 and 2, the mapped UDL implementation examples for the type VSSR are VIS.1.3.1.-1.3.4., VIS.2.2.6., SEN.1.5.7.-1.5.8., SEN.2.2.4., 
SEQ.1.5.10-1.5.12., SEQ.2.2.8., REF.1.5.5-1.5.6., and REF.2.2.3. Similarly, the mapped UDL implementation example for the type VSGA are VIS.1.3.1-1.3.4., VIS.2.2.6., SEN.1.5.7.-1.5.8., SEN.2.2.4., ACT.1.5.3-1.5.4., ACT.2.2.1.-2.2.2., GLO.1.5.13-1.5.15 and GLO.2.2.9.

Since two of the four students are type VSGA, UDL examples for type VSGA should be implemented first, followed by type VSSR if time and resources are allowed. It is noted that the UDL examples that map with "all types" should be implemented regardless of the learning styles.

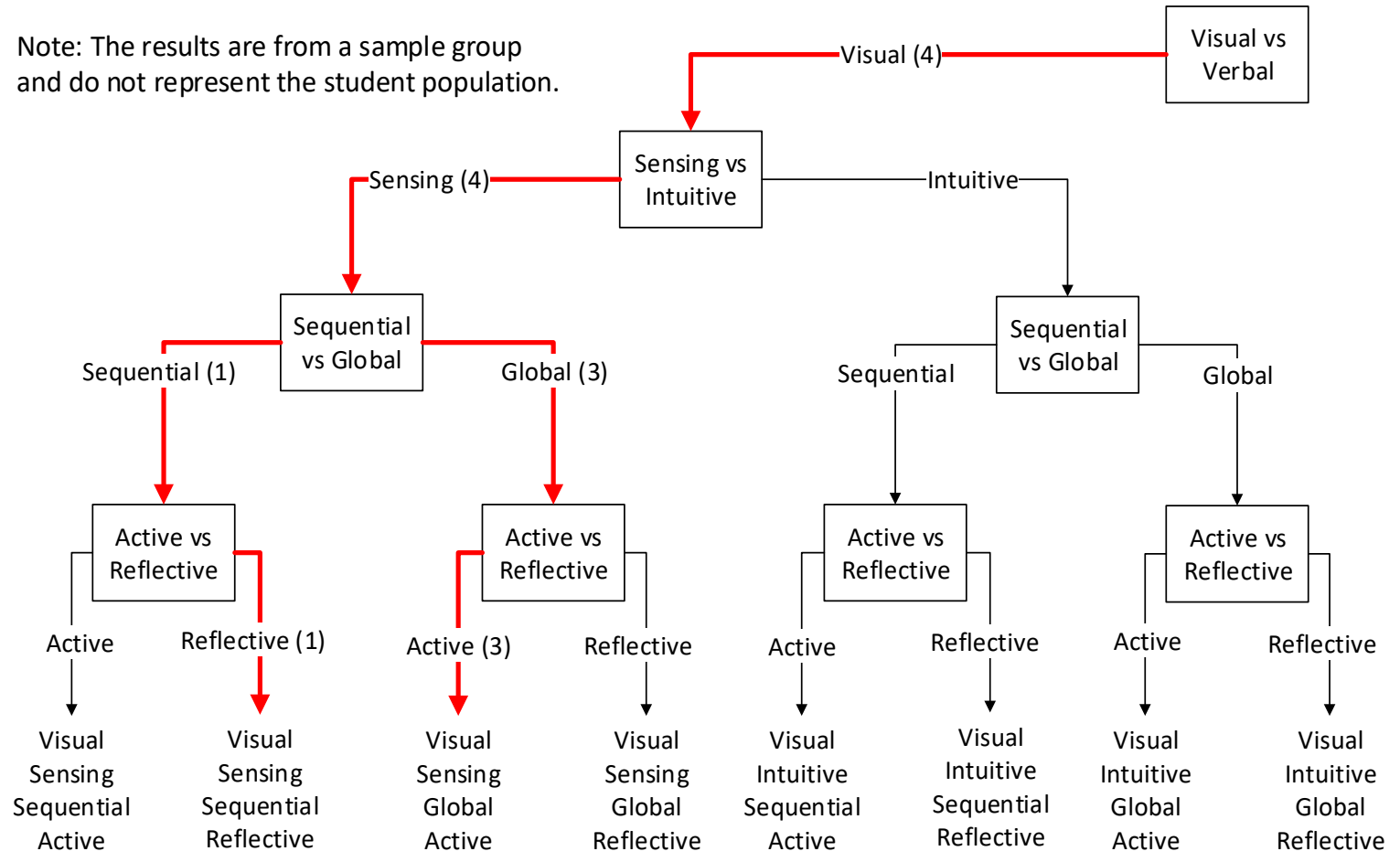

Figure 3. Details of the learning styles assessment results of the OU Aviation students.

Statistical analysis of the tallied number of responses within each learning style classification for the four students showed a different outcome of the mapped UDL examples. The plots based on the number of responses for each learning style the students answered are 
provided in Figure 4. Two learning style classifications, active/reflective and sequential/global, were much more balanced than the other learning style classifications, sensing/intuitive and visual/verbal. Mann-Whitney-Wilcoxon tests showed whether the students favored one learning style over another. For the active/reflective classification, students did not favor either style $(\mathrm{p}=$ $0.47, W=21.00$ ). For the sensing/intuitive classification, the results were marginally significant as students favored sensing $(\mathrm{p}=0.06, W=26.00)$. For the visual/verbal classification, the results were marginally significant as students favored visual $(p=0.06, W=26.00)$. For the sequential/global classification, students did not favor either style $(\mathrm{p}=0.44, W=17.00)$.

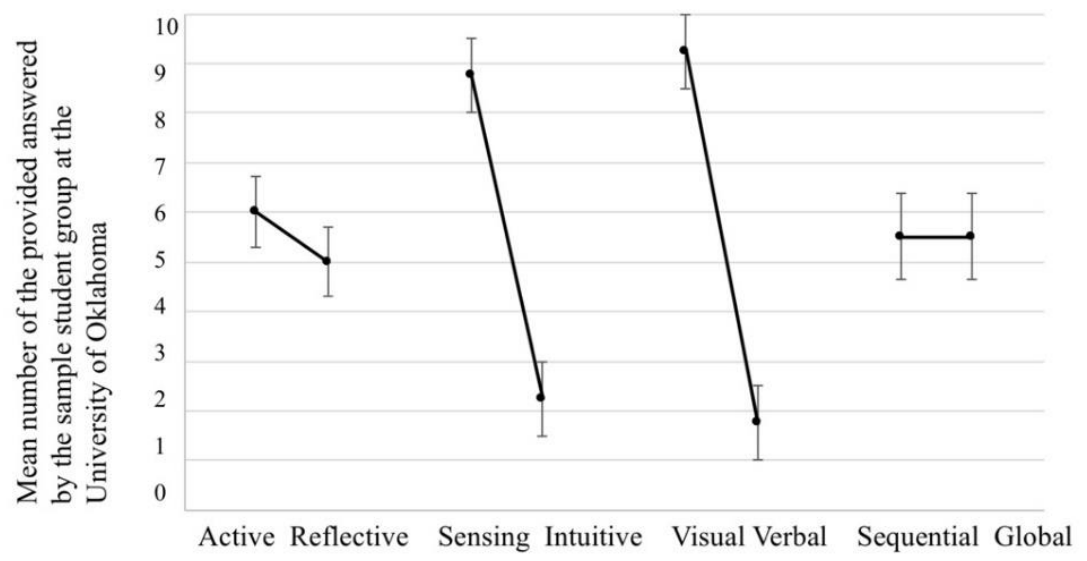

Figure 4. Plot of means and standard errors.

The statistical test indicated that the biggest mismatch of teaching style vs. learning style might arise from sensing/intuition and visual/verbal classifications. In this pilot study, the statistical analysis results indicate that the focus should be more on addressing the issues of sensing and visual learners; therefore, the mapped UDL examples are narrowed down to VIS.1.3.1-1.3.4., VIS.2.2.6., SEN.1.5.7.-1.5.8., and SEN.2.2.4. which should take highest implementation priorities over others if those UDL examples have not been previously implemented into the teaching curriculum. Since no significant differences were found in other 
classifications, the effect of implementing the UDL example of one learning style over another would be less than those identified as the highest priorities.

Classroom observations at the Department of Aviation at OU showed that some of the UDL methods were already well implemented while others were not as evident. The detailed classroom observation results based on the UDL methods are as follows.

Methods of representation at the OU Aviation Laboratory featured traditional PowerPoint lectures (AVIA 1013) and simulations (AVIA 4013 and AVIA 4023). AVIA 1013, Air Traffic Basics class, was taught with PowerPoint lectures of phraseology and images to accompany the verbal lecture. The PowerPoint came with audio cues that tested the students' ability to say the phrase while they were studying. The instructor interacted with the students, having them repeat phrases back to create a stronger mind-to-mouth connection. To aid in understanding more complex concepts, the instructor used the whiteboard to illustrate and highlight important details that better answered the students' questions. PowerPoint slides were made available on Canvas, an online file storage for classes, for student review. The TRACON and En Route simulation classes provided visual scenarios to students as a direct application of the material previously covered in classes. Students had to give an auditory response to the visual components, activating multiple pathways. Students in both classes used the 7110.65 Air Traffic Control Manual that features rules and phraseology for the field. It was provided in written text format, and it seemed that the students found it difficult to understand and learn without application in the classroom simulations. Additionally, students used LiveATC - a live broadcast of ATC towers across the United States.

The means of action and expression were then observed in the classroom. In the Air Traffic Basics course, the instructor gave examples to help the students distinguish between 
concepts, such as when to use "nine" or "niner." The instructor interacted with the students, asking them questions and testing their understanding of the material throughout the lesson. Students also took a 10-question short-answer quiz at the beginning of class that reviewed previous lectures. After the quiz, students were called on individually to answer each of the questions as a review. In the simulation classes, the students had a very high level of instructor feedback. In these classes, there were two instructors and a lab technician for three students. Instructors sat behind the students asking questions and giving instructions as the students ran through the simulation so that the students could organize their thought processes for the actions they were taking. They also had the ability to pause the scenario and clarify any confusion the students were experiencing. The students frequently asked questions of the instructors when they encountered a problem that was difficult to mitigate. In addition to class time, students had the option to practice in the lab on Fridays for a couple of hours. Instructors were available for the session to run the simulations for the students. Time was also provided to the students to practice scenarios with each other during the class, allowing them to pretend to be the plane and the controller to better practice the phraseology.

To foster engagement, at the beginning of the ATC Basics course, the instructor reemphasized the importance of the lecture. The lecture applied the previously learned phraseology, which provided challenges to students if they did not pay close attention. The interactive style of this lecture helped students pay better attention and focus during the class period.

\section{Discussion of the Proposed Approaches and Pilot Study Results}

The proposed approaches showed promise in identifying the highest priorities of the UDL methods that should be applied by identifying the preferred learning styles of a student group. If 
the size of the group is large, then we would be able to first apply the UDL methods that would map with the dominant preferred learning styles. If time and resources allowed, then the less dominant styles could be addressed. To better address the issues with learning styles, the mapped tables of learning styles and UDL methods proposed above can be used as a checklist to systematically identify the gaps and address those gaps given the limited time and resources.

It is important to note that the proposed approaches should be applied to every batch of new students since their dominant learning style might differ from others. Furthermore, the learning styles should be evaluated multiple times periodically since some students might have changed their preferred learning styles over the years of training.

The results from both the learning style mapping and the classroom observations at the Department of Aviation at OU indicate that there are already many UDL principles implemented into the teaching curriculum and that there can still be room for improvement to further support the students' learning styles using the proposed matching approach. Visual learners can be provided with scaffolding options such as introducing visual support tools when they verbally interact with the instructors during the laboratory sessions. For example, a separate monitor could be provided for the students to interact with the materials learned during class (e.g. PowerPoint slide notes) if they struggle understanding the verbal instructions provided by the instructor(s). In addition, sensing learners might benefit from going through many more example scenarios during their own time if the scenarios that they learn during the laboratory sessions are not sufficient to them. A scaffolding system that allows additional examples for the students to review could be provided (e.g. a software that can show the video recordings of the additional scenarios along with visual guidelines of how issues are addressed). As the students 
adapt to the verbal communications with the instructors and better understand the structure of the laboratory examples, then the scaffolds could be gradually removed.

The contributions of this pilot study are (1) developing a specific mapping approach between the learning styles and UDL methods that leaves out possible vagueness, (2) proposing an implementing approach to first address the needs of the dominant learning tendencies of a student group that can be expanded to a student population, and (3) demonstrating the capabilities of the adapted approaches. The examples laid out above are limited to better address the needs of the dominating preferred learning styles of the students who participated in the pilot study. Although the sample size was small, it was sufficient to evaluate the capabilities of our proposed evaluation approaches. It is important to note that if the characteristics of the population change, then the mapping results will be different. The proposed mapping approach and implementation process provide a foundation to effectively address the needs of the student population who might show specific tendencies of their preferred learning styles.

\section{Limitations and Future Research}

Although this research mapped the learning styles with the UDL methods to provide practical scaffolding implementation examples, there is much more room for improvement. This includes identifying as many implementation examples as possible, mapping the examples to the actual teaching materials (e.g. providing more specific examples using the contents within the current teaching course slides), and accommodating other factors such as diversified populations or language barriers.

In addition, the pilot study served the purpose of demonstrating our mapping and implementation approaches, noting that the outcomes support only the needs of the participants and should not be used to generalize the whole student population. Therefore, in order to 
provide a more generalized outcome from applying our approaches, we have currently received permission to interact with the FAA Academy trainees and instructors. Interviews and learning styles assessments are currently being conducted.

Furthermore, it is possible that the characteristics of the students who are entering the training program have been drastically changing due their exposure to technology, such as cell phones or virtual reality devices. They are comfortable with using technology and there has been research that the use of such technology can improve performance (Bacca, Baldiris, Fabregat, \& Graf, 2014; Farrokhnia \& Esmailpour, 2010; Goyal, Yadav, \& Choubey, 2012, Strangman, Hall, \& Meyer, 2003; Hew \& Cheung, 2010; Merchant, Goetz, Cifuentes, Keeney-Kennicutt, \& Davis, 2014). However, we do not know whether the application of the technologies will benefit the trainees at the FAA Academy. We need to investigate the possibilities of intertwining the learning styles, UDL, and the advanced available technologies (e.g. eye tracking embedded into wearable immersive VR devices) in the context of technical training. Application of the UDL and learning styles with the use of technology can be instrumental in creating a framework that can be applied to the training solution for the FAA.

\section{Acknowledgement}

This research was funded by the FAA Center of Excellence: Project No. A17-0160. We deeply thank the instructors and students in the Department of Aviation at the University of Oklahoma for their unconditional support to benchmark our adapted approaches. 


\section{References}

Bacca, J., Baldiris, S., Fabregat, R., \& Graf, S. (2014). Augmented reality trends in education: A systematic review of research and applications. Journal of Educational Technology \& Society, 17(4), 133.

Dean, T., Lee-Post, A., \& Hapke, H. (2017). Universal design for learning in teaching large lecture classes. Journal of Marketing Education, 39(1), 5-16. https://doi.org/10.1177/0273475316662104

Dell, C. A., Dell, T. F., \& Blackwell, T. L. (2015). Applying universal design for learning in online courses: Pedagogical and practical considerations. Journal of Educators Online, 12(2), 166-192. https://doi.org/10.9743/JEO.2015.2.1

Edyburn, D. L. (2010). Would you recognize universal design for learning if you saw it? Ten propositions for new directions for the second decade of UDL. Learning Disability Quarterly, 33(1), 33-41. https://doi.org/10.1177/073194871003300103

Farrokhnia, M. R., \& Esmailpour, A. (2010). A study on the impact of real, virtual and comprehensive experimenting on students' conceptual understanding of DC electric circuits and their skills in undergraduate electricity laboratory. Procedia-Social and Behavioral Sciences, 2(2), 5474-5482. https://doi.org/10.1016/j.sbspro.2010.03.893

Felder, R. M., \& Brent, R. (2005). Understanding student differences. Journal of Engineering Education, 94(1), 57-72. https://doi.org/10.1002/j.2168-9830.2005.tb00829.x

Felder, R. M., \& Silverman, L. K. (1988). Learning and teaching styles in engineering education. Engineering Education, 78(7), 674-681.

Felder, R. M., \& Soloman, B. A. (n.d.). Index of learning styles questionnaire. In North Carolina State University. Retrieved from https://www.webtools.ncsu.edu/learningstyles/ 
Felder, R. M., \& Soloman, B. A. (2000). Learning styles and strategies. Retrieved from http://www4.ncsu.edu/unity/lockers/users/f/felder/public/ILSdir/styles.htm

Fuentes, S. S., Castro, L., Casas, J. A., Vallejo, V., \& Zuñiga, D. (2016). Teacher perceptions based on universal design for learning. Communication Disorders, Deaf Studies \& Hearing Aids, 4(1), 155.

Gonzales, L. K., Glaser, D., Howland, L., Clark, M. J., Hutchins, S., Macauley, K., . . \& \& Ward, J. (2017). Assessing learning styles of graduate entry nursing students as a classroom research activity: A quantitative research study. Nurse Education Today, 48, 55-61. https://doi.org/10.1016/j.nedt.2016.09.016

Goyal, M., Yadav, D., \& Choubey, A. (2012). E-learning: Current state of art and future prospects. International Journal of Computer Science, 9(3), 490-499.

Hall, T. E., Meyer, A., \& Rose, D. H. (Eds.). (2012). Universal Design for Learning in the Classroom: Practical Applications. New York, NY: Guilford Press.

Hawk, T. F., \& Shah, A. J. (2007). Using learning style instruments to enhance student learning. Decision Sciences: Journal of Innovative Education, 5(1), 1-19. https://doi.org/10.1111/j.1540-4609.2007.00125.x

Hew, K. F., \& Cheung, W. S. (2010). Use of three-dimensional (3-D) immersive virtual worlds in K-12 and higher education settings: A review of the research. British Journal of Educational Technology, 41(1), 33-55. https://doi.org/10.1111/j.1467-8535.2008.00900.x

Hitchcock, C., Meyer, A., Rose, D., \& Jackson, R. (2002). Providing new access to the general curriculum: Universal design for learning. Teaching Exceptional Children, 35(2), 8-17. https://doi.org/10.1177/004005990203500201 
Hwang, G. J., Sung, H. Y., Hung, C. M., \& Huang, I. (2013). A learning style perspective to investigate the necessity of developing adaptive learning systems. Educational Technology \& Society, 16(2), 188-197.

Khenissi, M. A., Essalmi, F., Jemni, M., Kinshuk, Graf, S., \& Chen, N. S. (2016). Relationship between learning styles and genres of games. Computers \& Education, 101, 1-14. https://doi.org/10.1016/j.compedu.2016.05.005

Morra, T., \& Reynolds, J. (2010). Universal design for learning: Application for technologyenhanced learning. Inquiry: The Journal of the Virginia Community Colleges, 15(1), 5.

Merchant, Z., Goetz, E. T., Cifuentes, L., Keeney-Kennicutt, W., \& Davis, T. J. (2014). Effectiveness of virtual reality-based instruction on students' learning outcomes in K-12 and higher education: A meta-analysis. Computers \& Education, 70, 29-40. https://doi.org/10.1016/j.compedu.2013.07.033

Rose, D. (2000). Universal design for learning. Journal of Special Education Technology, 15(4), 47-51. https://doi.org/10.1177/016264340001500407

Rose, D. H., Harbour, W. S., Johnston, C. S., Daley, S. G., \& Abarbanell, L. (2006). Universal design for learning in postsecondary education: Reflections on principles and their application. Journal of Postsecondary Education and Disability, 19(2), 135-151.

Rose, D. H., \& Meyer, A. (2002). Teaching Every Student in the Digital Age: Universal Design for Learning. Alexandria, VA: Association for Supervision and Curriculum Development.

Rose, D. H., Meyer, A., \& Hitchcock, C. (2005). The Universally Designed Classroom: Accessible Curriculum and Digital Technologies. Cambridge, MA: Harvard Education Press. 
Schelly, C. L., Davies, P. L., \& Spooner, C. L. (2011). Student perceptions of faculty implementation of universal design for learning. Journal of Postsecondary Education and Disability, 24(1), 17-30.

Strangman, N., Hall, T., \& Meyer, A. (2003). Virtual reality/computer simulations and the implications for UDL implementation. Wakefield, MA: National Center on Accessing the General Curriculum. Retrieved from http://sde.ok.gov/sde/sites/ok.gov.sde/files/VirtualRealityUDL_000.pdf

Tobin, T. J. (2016). Two radical shifts in how and why higher-education distance-learning administrators should promote universal design for learning. Proceedings of the DLA2016 Conference, Jekyll Island, GA, 219-230. Retrieved from https://www.westga.edu/ distance/dla/pdf/2016-DL-PROCEEDINGS-updated.pdf

UDL Guidelines. (2014, July 31). Retrieved from http://www.udlcenter.org/aboutudl/udlguidelines 